\title{
A study to find the correlation between mucocutaneous manifestations and CD4 counts among the newly diagnosed HIV individuals.
}

\author{
Kumar Patjoshi S. ${ }^{1}$, Chandra T. ${ }^{*}$ \\ DOI: https://doi.org/10.17511/ijmrr.2020.i01.20 \\ ${ }^{1}$ Subhodha Kumar Patjoshi, Assistant Professor, Department of Dermatology, Veer Surendra Sai Institute Of Medical Science And Research, \\ Burla, Odisha, India. \\ ${ }^{2 *}$ T Jaya Chandra, Associate Professor, Department of Microbiology, GSL Medical College, Rajahmundry, Andhra Pradesh, India.
}

Introduction: Skin disorders are common manifestations of HIV disease. A study was conducted to find the correlation between the degree of immunosuppression and the incidence of specific skin disorders in patients with HIV infection. Materials and methods: Study was conducted in the department of dermatology, SCB Medical College and Hospital, Cuttack from October 2010 to September 2012. Random sampling was considered in this study. Referred patients, after pretest counseling at ICTC Centre, were included and individuals who are on antiretroviral treatment were excluded. Relevant diagnostic tests were performed like scraping and $\mathrm{KOH}$ examination for the diagnosis of dermatophytoses and candidiasis, Tzanck smear for herpes infection, Darkfield microscopy for diagnosis of a syphilitic ulcer, Biopsy is done wherever required. CD4 count was done as per the guidelines. Results: A total of $150(100 \%)$ participants were included, the male-female ratio was 1.8 . Age-wise, $57 \%$ (85) were included in $31-45$ group and $15 \%$ were unmarried. Fungal infections constitute $17.9 \%$ of total mucocutaneous disorders followed by bacterial infections $(10.5 \%)$, viral $(8.09 \%)$ and parasitic $(6.7 \%)$ infestations. Conclusion: Age group, $31-45$ years is the commonest for HIV infection. Fungal infections (dermatoses) of the skin were most common followed by bacterial folliculitis, herpes zoster, and scabies. Except for viral infections, the mean CD4 counts were $<200$ cells/cu $\mathrm{mm}$.

Keywords: AIDS, CD4 counts, HIV, Infections

Corresponding Author

T Jaya Chandra, Associate Professor, Department of Microbiology, GSL Medical College, Rajahmundry, Andhra Pradesh, India.

Email: chanduthegreat2014@gmail.com
How to Cite this Article

To Browse

Patjoshi SK, Chandra TJ. A study to find the correlation between mucocutaneous manifestations and CD4 counts among the newly diagnosed HIV individuals.. Int J Med Res Rev. 2020;8(1):130-135. Available From https://ijmrr.medresearch.in/index.php/ijmrr/article/ view/1161

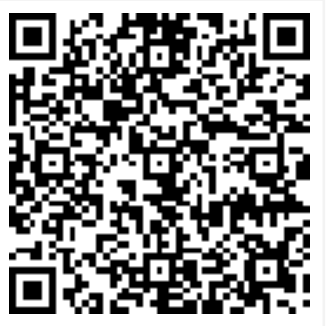

Manuscript Received 2020-01-28

Conflict of Interest No
Review Round 2 2020-02-14

Ethical Approval Yes
Review Round 3

Plagiarism X-checker $5 \%$
Accepted 2020-02-19

Note

(C) 2020 by Subhodha Kumar Patjoshi, T Jaya Chandra and Published by Siddharth Health Research and Social Welfare Society. This is an Open Access article licensed under a Creative Commons Attribution 4.0 International License https://creativecommons.org/licenses/by/4.0/ unported [CC BY 4.0]. 


\section{Introduction}

AIDS, the Acquired Immunodeficiency Syndrome is a fatal illness caused by a retrovirus known as Human Immunodeficiency Virus (HIV), was first recognized in the United States in the summer of 1981 [1]. The onset of the HIV epidemic in India was heralded by the detection of HIV in commercial sex workers (CSW) and a case of AIDS in Chennai and Mumbai respectively in 1986.

Progressive immune dysfunction is the hallmark of this viral infection. The RNA retrovirus infects CD4+ cells, most notably $T$ helper cells, and leads to a profound alteration of immune system function that predisposes patients to numerous opportunistic infections, malignancies, and neurologic disease. Patients progress to AIDS when CD4+ cell counts fall below 200 cells/cumm or certain clinical diseases manifest [2]. HIV is present in an infected person in all the body fluids, the highest concentration of virus being present in blood and genital secretions.

CD4 cell count is one of the essential investigations in the clinical evaluation and the management of HIV infected individuals. However, the standard test for CD 4 cell count requires sophisticated laboratory facilities, expertise and is expensive. It is not readily available in resource-poor settings [3]. The skin is richly endowed with CD4 T cells.

Cutaneous manifestations are prominent affecting up to $90 \%$ of HIV infected persons [4,5]. The skin lesions or combinations of skin conditions are so unique that the diagnosis of HIV/AIDS can often be suspected from the skin examination alone [4]. The skin conditions also tend to appear at a specific stage in the progression of HIV and like CD4 T cell count, is an indicator of the development of AIDS and overall survival.

Skin disorders are common manifestations of HIV disease. Patients with HIV disease are at an increased risk of a variety of common cutaneous conditions and suffer a wide range of infectious, inflammatory and malignant skin conditions. Decreased mucocutaneous immunity often accounts for the earliest clinical symptoms and signs in HIV infected patients.

It has become increasingly clear that cutaneous disorders are not only associated with terminal immunodeficiency but also occur throughout the course of HIV infection. More than $90 \%$ of HIV seropositive patients develop skin or mucous membrane conditions at some time during their
Disease and in many of the skin is the first organ affected.

As HIV disease progresses, these manifestations become more severe and varied, causing physical discomfort and psychological distress in otherwise relatively healthy individuals. In advanced immunosuppression, opportunistic pathogens can present as atypical cutaneous lesions presenting challenges in both diagnosis and treatment.

With these, a study was conducted to find the correlation between the degree of immunosuppression and the incidence of specific skin disorders in patients with HIV infection.

\section{Materials and Methods}

Settings: Study was conducted in the department of dermatology, SCB Medical College and Hospital, Cuttack.

Duration of study: The study was conducted from October 2010 to September 2012.

Sampling method: Random sampling was considered in this study.

Inclusion criteria: In suspected patients and referred patients, after pretest counseling screened at ICTC Centre of our hospital with three different types of tests (Enzyme Immune Assay or Rapid test) which are based upon a different antigen preparation or principle.

Exclusion criteria: Individuals who are on antiretroviral treatment, who did not submit the consent were not considered in the study.

Sample size: All the individuals who satisfy the inclusion criteria during the study period were included in the study.

Ethical approval: Study protocol was approved by the institutional ethical committee.

The complete history of each patient was taken. The patient underwent a thorough physical examination with emphasis on mucocutaneous manifestations.

Findings were recorded on proforma. Relevant diagnostic tests were performed like scraping and $\mathrm{KOH}$ examination for the diagnosis of dermatophytoses and candidiasis, Tzanck smear for herpes infection, Darkfield microscopy for diagnosis of a syphilitic ulcer, Biopsy is done wherever required. The patients were treated according to the WHO/CDC guidelines. 
A complete record along with baseline CD4 count and CD4 count is done before the appearance of specific dermatological manifestations was recorded in proforma enclosed herewith. The data were analyzed using SPSS Version 21.0. Statistics in the form of mean and percentage were included in the study.

\section{Results}

In this study total, $150(100 \%)$ participants were included. Among these 96 (64\%) were male and 54 (36) were female participants; the male-female ratio was 1.8. Age-wise, 5\% (8) participants were included in the < 15 years group, 27\% (40) were included in the 16-30 years group, 57\% (85) were included in $31-45$ years group and $11 \%$ (17) in $>45$ years age group.

Gender wise, in male, 2\% (3) participants were included in < 15 years group, $8 \%$ (12) were included in $16-30$ years group, $43 \%$ (68) were included in 31-45 years group and $9 \%$ (13) in $>45$ years age group; among the female, 3\% (5) participants were included in $<15$ years group, $19 \%$ (28) were included in $16-30$ years group, $11 \%$ (17) were included in $31-45$ years group and $2.5 \%$ (4) in $>45$ years age group (Table 1 ).

Table-1: Age and gender-wise distribution of the study participants; $\mathbf{n}(\%)$.

\begin{tabular}{|l|l|l|l|}
\hline \multicolumn{1}{|c|}{ Age } & \multicolumn{1}{|c|}{ Male } & \multicolumn{1}{c|}{ Female } & \multicolumn{1}{c|}{ Total } \\
\hline$<15$ & $3(2)$ & $5(3)$ & $8(5)$ \\
\hline $16-30$ & $12(8)$ & $28(19)$ & $40(27)$ \\
\hline $31-45$ & $68(43)$ & $17(11)$ & $85(57)$ \\
\hline$>45$ & $13(9)$ & $4(2.5)$ & $17(11)$ \\
\hline Total & $96(64)$ & $54(36)$ & $150(100)$ \\
\hline
\end{tabular}

Out of the 150 (100\%) study participants, 15\% (23) were unmarried, 66\% (99) were married, $11 \%$ (16) were widowed, $3 \%$ (4) divorced and this was not applicable for $5 \%$ (8) of the participants. In the male, $11 \%$ (17) were unmarried, $47 \%$ (70) were married, $2.5 \%$ (4) were widowed, $1.3 \%$ (2) divorced and this was not applicable for $2 \%$ (3). Among the female, 4\% (6) were unmarried, $19 \%$ (29) were married, $8 \%$ (12) were widowed, $1.3 \%$ (2) divorced and this was not applicable for $3.3 \%$ (5) (Table 2).

Table-2: Distribution of study participants according to marital status; $\mathbf{n}(\%)$.

\begin{tabular}{|l|l|l|l|}
\hline \multicolumn{1}{|c|}{ Marital status } & \multicolumn{1}{c|}{ Male } & \multicolumn{1}{c|}{ Female } & \multicolumn{1}{c|}{ Total } \\
\hline Unmarried & $17(11)$ & $6(4)$ & $23(15)$ \\
\hline Married & $70(47)$ & $29(19)$ & $99(66)$ \\
\hline
\end{tabular}

\begin{tabular}{|l|l|l|l|}
\hline Widowed & $4(2.5)$ & $12(8)$ & $16(11)$ \\
\hline Divorced & $2(1.3)$ & $2(1.3)$ & $4(3)$ \\
\hline Not applicable & $3(2)$ & $5(3.3)$ & $8(5)$ \\
\hline Total & $96(64)$ & $54(36)$ & $150(100)$ \\
\hline
\end{tabular}

There were 30 patients with bacterial infections, and it constitutes $10.5 \%$ of total mucocutaneous disorders. Out of this folliculitis was the most common bacterial infection seen in 19 patients $(64 \%)$, out of which $63 \%$ with CD4 count $<200$ cells/cumm.

This was followed by 3 patients (10\%) with impetigo, 2 patients (6.6\%) each with abscess and ecthyma, 1 each with cellulitis, Hansen's disease, cutaneous TB and primary syphilis (Table 3 ).

Table-3: Correlation between CD4 count and bacterial skin infections among the study participants; n (\%).

\begin{tabular}{|l|l|l|l|l|}
\hline \multirow{2}{*}{ Bacterial infections } & \multicolumn{3}{|c|}{ CD4 Count (cells/cu mm) } & \multirow{2}{*}{ Total } \\
\cline { 2 - 4 } & $<200$ & $200-500$ & $>500$ & \\
\hline Folliculitis & $12(40)$ & $7(23)$ & 0 & $19(63)$ \\
\hline Abscess & $1(3.3)$ & $1(3.3)$ & 0 & $2(7)$ \\
\hline Impetigo & $1(3.3)$ & $2(7)$ & 0 & $3(10)$ \\
\hline Cellulitis & $1(3.3)$ & 0 & 0 & $1(3.3)$ \\
\hline Ecthyma & $1(3.3)$ & $1(3.3)$ & 0 & $2(7)$ \\
\hline Hansens & $1(3.3)$ & 0 & 0 & $1(3.3)$ \\
\hline Cutaneous TB & $1(3.3)$ & 0 & 0 & $1(3.3)$ \\
\hline Syphillis & $1(3.3)$ & 0 & 0 & $1(3.3)$ \\
\hline Total & $19(63)$ & $11(37)$ & 0 & $30(100)$ \\
\hline
\end{tabular}

Fungal infections were seen in 51 patients constitutes $17.9 \%$ of total mucocutaneous disorders.

Table-4: Correlation between CD4 count and fungal infections among the study participants; n (\%).

\begin{tabular}{|l|l|l|l|l|}
\hline \multicolumn{1}{|c|}{ Fungal infections } & \multicolumn{2}{c|}{ CD4 Count (cells/cumm) } & \multirow{2}{*}{ Total } \\
\cline { 2 - 4 } & $<200$ & $200-500$ & $>500$ & \\
\hline T. Cruris & $7(14)$ & $2(4)$ & $2(4)$ & $11(22)$ \\
\hline T. Corporis & $6(12)$ & $2(4)$ & 0 & $8(16)$ \\
\hline T. Manuum & $1(2)$ & 0 & 0 & $1(2)$ \\
\hline T. Pedis & $2(4)$ & 0 & 0 & $2(4)$ \\
\hline Intertrigo & $2(4)$ & $1(2)$ & $1(2)$ & $4(8)$ \\
\hline Oral Candidiasis & $11(22)$ & $4(8)$ & $1(2)$ & $16(31)$ \\
\hline Vulvovaginal candidiasis & $4(8)$ & $2(4)$ & 0 & $6(12)$ \\
\hline Candidial balanoposthitis & $2(4)$ & $1(2)$ & 0 & $3(6)$ \\
\hline Total & $35(69)$ & $12(23.5)$ & $4(8)$ & $51(100)$ \\
\hline
\end{tabular}

Oral candidiasis most common found in 16 patients (31\%) with the majority ( $69 \%$ ) with CD4 count $<200$ cells/cumm, 8 patients $(15.7 \%)$ with $\mathrm{T}$. corporis and 6 patients $(11.76 \%)$ with vulvovaginal 
Candidiasis, followed by 3 patients $(5.88 \%)$ candidal balanoposthitis, 4 patients (7.84\%) with intertrigo, 2 patients $(3.92 \%)$ with T. pedis, 1 patients with T. manuum (1.96\%) (Table 4 ).

There were 23 patients, around $8.09 \%$ of total mucocutaneous manifestations with viral infections. Out of which 7 patients (30.4\%) with herpes genitalis, 6 patients $(26.08 \%)$ with herpes zoster, 5 patients $(21.7 \%)$ herpes labialis, 3 patients (13\%) with molluscum contagiosum, 2 patient $(8.7 \%)$ with the genital wart. A total of $48 \%$ of viral infection patients with $<200$ CD4 cells/cu mm (Table 5).

Table-5: Correlation between CD4 count and viral infections among the study participants; n (\%).

\begin{tabular}{|l|l|l|l|l|}
\hline \multirow{2}{*}{ Viral infections } & \multicolumn{3}{|c|}{ CD4 Count (cells/cu mm) } & \multirow{2}{*}{ Total } \\
\cline { 2 - 4 } & $<200$ & $200-500$ & $>500$ & \\
\hline H. Zoster & $4(17)$ & $2(8.5)$ & 0 & $6(26)$ \\
\hline H. Genitalis & $4(17)$ & $2(8.5)$ & $1(4.5)$ & $7(30)$ \\
\hline H. labialis & $2(8.5)$ & $3(13)$ & 0 & $5(22)$ \\
\hline M. Contagiosum & $1(4.5)$ & $2(8.5)$ & 0 & $3(13)$ \\
\hline Genital Wart & 0 & $2(8.5)$ & 0 & $2(9)$ \\
\hline Total & $11(48)$ & $11(48)$ & $1(4.5)$ & $23(100)$ \\
\hline
\end{tabular}

Parasitic infestations are seen in 19 patients, 6.7\% of total mucocutaneous manifestations, out of which 17 patients $(89.4 \%)$ patients with scabies, 1 patient $(5.26 \%)$ each with demodicidosis and pediculosis. $57.9 \%$ of scabies patients having CD4 count $<200$ cells/cu mm (Table 6).

Table-6: Correlation between CD4 count and parasitic infections among the study participants; n (\%)

\begin{tabular}{|l|l|l|l|l|}
\hline \multirow{2}{*}{ Parasitic infestations } & \multicolumn{3}{|c|}{ CD4 Count (cells/cumm) } & \multirow{2}{*}{ Total } \\
\cline { 2 - 4 } & $<200$ & $200-500$ & $>500$ & \\
\hline Scabies & $11(58)$ & $4(20)$ & $2(10)$ & $17(89)$ \\
\hline Demodicidosis & $1(5)$ & 0 & 0 & $1(5)$ \\
\hline Pediculosis & 0 & $1(5)$ & 0 & $1(5)$ \\
\hline Total & $12(63)$ & $5(26)$ & $2(10)$ & $19(100)$ \\
\hline
\end{tabular}

\section{Discussion}

Cutaneous manifestations of HIV infection have been the subject of intense scrutiny because the skin is the most commonly affected organ in HIV infected individuals. Infectious and non-infectious HIV induced skin diseases may not only serve as the marker of HIV infection but also as a marker of the stage of HIV disease and level of immunosuppression which is very important in resources poor countries where the most frequent evaluation of immunity with CD4 count cannot be
Done due to economical reasons.

The present study further revealed a correlation of the degree of immune suppression (as measured by CD4 count) and the incidence of specific skin disorders in patients with HIV/AIDS alongside establishing the clinical mucocutaneous indicators of the underlying immune status.

Out of 150 cases, 96 (64\%) were male and 54 $(36 \%)$ were female participants. The high male prevalence is consistent with the studies of Shobhana et al [5], Singh $\mathrm{H}$ et al [6], X-Huang et al [7], Josephine et al [8]. The high prevalence of in male accounted for migratory nature of their occupations and under-reporting of infection among the female.

In this study, $31-45$ years is the most common age group affected (56.6\%) followed by 15 - 30 years $(26.6 \%)$. These findings were comparable with Bravo et al [9]. These investigators reported that the prevalence was high (51\%) in the $30-39$ years age group. This seems to be related to high-risk sexual behavior in this age group. Among 150 patients $73 \%$ of males and $54 \%$ of females were married. Shobhana A et al. showed $65 \%$ of males and $95 \%$ of females were married [5].

The majority of the patients (42\%) were unskilled laborers, which were mostly included daily wage workers, followed by $24.6 \%$ of patients who were skilled laborers. This is because the hospital renders free service and hence is attended more by people belonging to the middle and low economic group. Among the women, the majority (24) patients were housewives. This again emphasizes the main route and source of infection in females i.e. through heterosexual contact with their spouse.

Bacterial infections were identified in 30 patients constitutes $10.5 \%$ of total mucocutaneous disorders. Folliculitis was the most common manifestations (6.6\%). This was comparable with the study by Sud et al. and Srikant KP et al., $8 \%$ of folliculitis lesions were reported $[9,10]$. The mean CD4 count in bacterial infection was 220.2 cells/cu $\mathrm{mm}$, this was reported to be 245.33 cells/cu $\mathrm{mm}$ by Jing et al [11].

Dermatophytoses was diagnosed in $8.4 \%$ of the study members. Whereas dermatological manifestations were reported to be $13 \%$ by Shobhana et al [5] and $11.7 \%$ by Attili et al [12]. In this study, Candidiasis was the common (49\%) fungal infection. Among the fungal infected 
Individuals, in the majority (68\%) the CD4 count was $<200$ cells/cu mm.

The mean CD4 count for oropharyngeal candidiasis in this study was 178.62 cells/cu $\mathrm{mm}$ and the mean CD4 counts were reported to be $150.8 \mathrm{cells} / \mathrm{cu} \mathrm{mm}$ [10]. In the available studies also, oral candidiasis was the most commonly reported mucocutaneous manifestations $[5,7,11,12]$. The mean CD4 count for fungal infections was 187.71 cells/cu $\mathrm{mm}$ and it was reported as 178 cells/cu mm by Kumarswamy et al. study [13].

In this study, there were 23 patients $(8.09 \%)$ with viral infections. The mean CD4 count was 260.84 cells/cu mm. Among the viral infections, herpes simplex virus causing herpes genitalis and herpes labialis were frequent. Herpes gentalis was diagnosed in $2.4 \%$ of patients. Jing et al. also reported similar findings [11].

The mean CD4 count in herpes genitalis infected individuals was 232.42 cells/cu $\mathrm{mm}$ and it was reported as 187 cells/ cu mm, 211.5 cell/cu mm respectively by Shobhana et al [5] and Srikant KP et al [10]. Most cases improved with Oral Acyclovir therapy. The majority (57\%) of herpes genitalis cases were having CD4 count $<200$ cells/cumm.

Herpes Zoster was seen in 6 patients $(2.1 \%)$, this was lower than the study by Shobhana et al [5]. This difference may be due to under-reporting of cases. The mean CD4 count was 168.33 cells/cu $\mathrm{mm}$ and in the available literature, the mean $\mathrm{CD} 4$ counts were 152 cells/cu $\mathrm{mm}$ and 138.3 cells/cu $\mathrm{mm}$ respectively by Wahard et al [14] and Attili et al [12].

Molluscum contagiosum was found in 3 patients $(1.05 \%)$ with mean CD4 count of 217 cells/cu mm. The mean CD4 counts were similar as reported by Nnoruka et al [15]. One patient in this study had giant molluscum over face and one with multiple giant lesions surrounding the orbital area. Genital wart was found in 2 cases and the CD4 count was 423 cells / $\mathrm{cu} \mathrm{mm}$ and 407cells/cu mm, /respectively.

Parasitic infestations were identified in $6.6 \%$ of patients. Scabies was the predominant $(17 ; 5.9 \%)$ parasitic infection. In the literature, the incidence of scabies varies between $3-6 \%[15,16,17]$. But Attili et al. revealed similar findings [12]. The mean CD4 count in this study was 197.94 cells/cu mm, this was lower than the available studies [12].

\section{Conclusion}

Active age group, $31-45$ years is the commonest for HIV infection and most of them were unskilled laborers. Fungal infections of the skin were most common among the infectious dermatoses, with mean CD4 count 187.7 cells/cu $\mathrm{mm}$ in bacterial infections folliculitis was the commonest infections, mean CD4 count was 204.4cells/cu mm. Herpes zoster is the common viral skin infection, the mean CD4 count was 262.44 cells/cu mm. Scabies was found in $5.9 \%$ with mean CD4 count 197.9 cells/cu $\mathrm{mm}$.

\section{Limitations}

Small sample size, short study period are the limitations of this research.

\section{What does this study add to the existing knowledge}

Below 45 years is the common age group for HIV infections and fungal skin infections are most common followed by bacterial, viral and parasitic infections. In fungal infections, oral Candidiasis is the predominate followed by T. Cruris. Folliculitis is a common bacterial infection in HIV patients.

\section{Author's contribution}

Dr. Subhodha Kumar Patjoshi: Sample collection, Benchwork, statistical analysis, paper writing

Dr. T Jaya Chandra: Literature survey, Paper writing, data analysis

\section{Reference}

01. Colven R. 25 Years of HIV/AIDS- A Dermatologist Epidemic Watcher's Perspective. Dermatol Clin. 2006; 24(4)407-412.

doi: [Article] [Crossref]

02. Garman ME, Trying SK. The cutaneous manifestations of HIV infection. Dermatol Clin. 2002;20;193-208.

doi: [Article] [Crossref]

03. Nnoruka E N, Chukwuka J C, Anisuba B. Correlation of mucocutaneous manifestations of HIV/AIDS infection with CD4 count and disease progression. Int J Dermatol. 2007;46(2)14-18. doi: [Article] [Crossref] 
04. James WD, Berger TG, Elston DM. Viral diseases, Andrew's Diseases of the Skin, Clinical Dermatology. 10th ed, Saunders, Elsevier. 2006; pp-367-420

[Crossref]

05. Shobhana A, Guha SK, Neogi DK. Mucocutaneous manifestations of HIV infection. Indian J Dermatol Venereol Leprol. 2004;70(2)82-86.

Available at [Article] [Crossref]

06. Singh H, Prabhakar S, Pavan T, Dey V, Dulhani $N$, Singh A. Dermatological manifestations in HIV-infected patients at a tertiary care hospital in a tribal region of Chhattisgarh. Indian J Dermatol. 2009;54(4)338-341. doi: [Article] [Crossref]

07. Xiao-Jie H, Hai-Ying L, De-xi C, Xi-Cheng W, ZaiChun $L$, Ya-Song $W$, et al. Clinical analysis of skin lesions in 796 chinese HIV-positive patients. Acta Derm Venereol. 2011;91(5)3-7. doi: [Article] [Crossref]

08. Josephine M, Issac E, George A, Ngole M, Albert SE. Pattern of skin manifestation and their relationships with CD4 counts among HIV/AIDS patients in cameroon. Int J Dermatol. 2006;45(3)280-284.

doi: [Article] [Crossref]

09. Sud N, Shanker V, Sharma A, Sharma NL, Gupta M. Mucocutaneous manifestations in 150 HIV infected indian patients and their relationship with CD4 lymphocyte count. Int J STD AIDS. 2009;20(11)771-774. doi: [Article] [Crossref]

10. Sen S, Mandal S, Bhattacharya S, Halder S, Bhaumik P. Oral manifestations in human immunodeficiency virus infected patients. Ind J Dermat. 2010;55(1)116-118. doi: [Article] [Crossref]

11. Jing W, Ismail R. Mucocutaneous manifestations of HIV infection- a retrospective analysis of 145 cases in a Chinese population in Malaysia. Int J Dermatol. 1999;38(6)457-463.

doi: [Article] [Crossref]

12. Attili VSS, Singh VP, Shyam Sundar A, AK Gulati, DV Varma, M Rai. Relationship between skin disease and CD4 cells counts in a hospital based cohort of HIV-infected Adults in North India. J Ind Acad Clin Med. 2008;9(1)20-25.

[Crossref]
13. Kumarasamy N, Solomon $S$, Madhivanan $P$, Ravikumar B, Thyagarajan SP, Yesudian $\mathrm{P}$. Dermatologic manifestations among human immunodeficiency virus patients in South India. Int J Dermat. 2000;39(3)192-195.

doi: [Article] [Crossref]

14. Ward HA, Russo GG, Shrum J. Cutaneous manifestation of anti-retroviral therapy. J Am Acad Dermatol. 2002;46(2)284-293.

doi: [Article] [Crossref]

15. Nnoruka E N, Chukwuka J C, Anisuba B. Correlation of mucocutaneous manifestations of HIV/AIDS infection with CD4 count and disease progression. Int J Dermatol. 2007;46(2)14-18. doi: [Article] [Crossref]

16. Goh BK, Chan RK, Sen $\mathrm{P}$, Theng CT, Tan $\mathrm{HH}$, Wu $Y$, et al. Spectrum of skin disorders in human immunodeficiency virus infected patients in Singapore and the relationship to CD4 lymphocyte counts. Int J Dermatol. 2007;46(7)695-699.

doi: [Article] [Crossref]

17. Smith KJ, Skelton H. Molluscum contagiosumrecent advances in pathogenic mechanisms, and new therapies. Am J Clin Dermatol. 2002;3(8)535-545. doi: [Article] [Crossref] 